\title{
DIGITAL BUSINESS AND MEDIA PLATFORMS - ENABLERS OF MANIFOLD REGIONAL AND GLOBAL OPPORTUNITIES
}

\author{
Sigitas BRAZINSKAS $\mathbb{B}^{1 *}$, Vida PIPIRIENE ${ }^{2}$, Shukrullo KHAYRZODA ${ }^{3}$ \\ ${ }^{1}$ Value Development, 08318, Vilnius, Lithuania \\ ${ }^{2}$ Department of International Economics and Business Management, Faculty of Business Management, \\ Vilnius Gediminas Technical University, 102213, Vilnius, Lithuania \\ ${ }^{3}$ Tajik State University of Finance and Economics, 734067, Dushanbe, Tajikistan \\ ${ }^{*}$ E-mail: sigitas.brazinskas@value.lt
}

\begin{abstract}
Purpose - digital platforms play a growing role in business development and create opportunities beyond earlier existed boundaries as countries, regions and industrial sectors. Industrial Internet concepts as a holistic application emerge, disruptive challenges trigger changes and evolution of existing business models. This paper unravels and analyses models and features of networks, market places, media platforms across various sectors along with arising opportunities.
\end{abstract}

Research methodology - research is based on benchmarking across selected digital platforms and impact analysis according to defined criteria and selected business models.

Findings - results justify scientific approach and contribute with a benchmarked view across different sectoral platforms, assess opportunities of the emerging digital era. The evolution of business patterns and the impact on changing models are key findings of the paper.

Research limitations - a certain number of platform models and their features are analyzed as well as impact, represented sectors are largely grouped.

Practical implications - results will have substantial practical application to business strategies adjustment, updated view on existing transformations across several business sectors and emerging business models.

Originality/Value - a united view is possessed on different platforms across regions and sectors, it combines several integrated angles towards digital development and provides with clear and applicable solutions.

Keywords: business market place, media platform, networks, industrial internet of things, efficiency, digitalization, regionalization.

JEL Classification: O31, L86.

Conference topic: Digitalization of Business Processes: Trends, Challenges, Solutions.

\section{Introduction}

The key purpose of the current paper is to analyze and benchmark digital sectoral platforms, assess their roles as enablers of manifold business opportunities even with a disruptive character. Economy digitalization and its transformation are on the global agenda to maintain and strengthen competitiveness and nations social well-being. The integration of digital technologies to the economy is a key component along with communication, connectivity, digital public services, skills, the share of information. In such a general platform-driven platform economy digital and physical marketplaces along with manufacturing technologies enable competitive future firms with smart manufacturing. Furthermore, such an economy unites numerous of economic activities that use digitized information and knowledge as key factors of production (Cisneros-Cabrera, Ramzan, Sampaio, \& Mehandjiev, 2017; European Commission, 2018; OECD, 2017; International Trade Center, 2016). Digital is meant to connect people, devices and physical objects anywhere flawlessly, instantly and freely (Bughin, Catlin, Hirt, \& Willmott, 2018). Digitalization and growing level of technological applications evolve and unite numerous concepts and measures used separately or synonymously in the digital economy as Industrial Internet Consortium, Industry 4.0, digital platforms, Machine-to-Machine Communications (M2M), efficient resource planning solutions and other (Institute of Electrical and Electronic Engineers, 2018). The fourth industrial revolution is driven by several factors including one of the most important as digital platforms, 
new business models based on data availability emerge. These models possess a disruptive character. An essential question is set on drivers of these changes: what is more important to have-assets or platforms and networks (Schwab, 2016).

Policy makers as governments and agencies along with policy implementers and business are teamed and committed to implement national digital strategies, implement economic activities that use digitized information and knowledge and facilitate these movements through programs and initiatives towards competitiveness enhancement and sustainable development of economic unions, regions, countries, cities and business in general at a large scale. Information and communication technologies (ICT) have become an imminent and integral part to maintain stable functioning of companies. It covers interaction between companies, reflects their marketing visibility and communication with customers, a degree of positioning in a value chain. Global value chains change pattern by the impact of crossborder data flows and new technologies, including digital platforms, the Internet of Things. Digital economy and development are tightly connected to data consolidation, it has become a significant business segment worldwide. Many companies started to outsource selected services to external providers and provide them with mandates to process, store and use information and data. Information brokers have a significant amount of information, on the other hand, they create networks and enable companies to use and benefit from this infrastructure. Companies allocate substantial resources to chip off the information flow on digital space (Eurostat, 2019; McKinsey Global Institute, 2019; Asian Development Bank, 2018; OECD, 2017; Stephens-Davidowitz, 2017; Kitchin, 2014). Gig economy concept as platform-mediated enabler contributes to international business opportunities across regions and countries. However, this concept is not equally applied across different countries. Some digital platform owners provide solutions on a global scale where other countries use it and have good leads, both approaches possess a different degree of applicability (ETLA, 2018). Platform economy is widely analyzed in researches, it becomes a work object in areas as social networks, advertising, communication. A wider approach is demanded to analyze industry related platforms as enablers of business opportunities. The paper uses a benchmarking method to assess several digital platforms by sectors and measure their benefit impact to target vendors segments across several industries and service sectors.

\section{Theoretical background}

Industrial internet concepts emerge and require expanded forms of effective cooperation between suppliers and buyers. In order to remain competitive, industries constantly demand reliable partners with competence, skilled personnel and industrial knowledge, sustainable and long-lasting business strategies, international business development and networking (Brazinskas, 2018). Izgorodin (2018) argues that the "Industry 4.0" concept was not widely applied and known as well as used. But a breakthrough is on the verge, just several examples indicated very obviously that the fourth industrial revolution in Europe has already begun. Users started moving from a device to a cloud, the Internet fulfills the role of the core meta-platform to which all others connect to run a certain business (Pon, Seppälä \& Kenney, 2015).

According to Eurostat (2019), EU-28 enterprises purchase more via computer-mediated networks. The percentage of enterprises rose from $35 \%$ in 2012 to $45 \%$ in 2017, a significant change just within the last five years. At least onefifth of EU-28 enterprises have received orders via such networks. ICT related functions performed by own employees tend to decline since 2016 where a share of outsourced functions possesses a growing trend (see Figure 1).

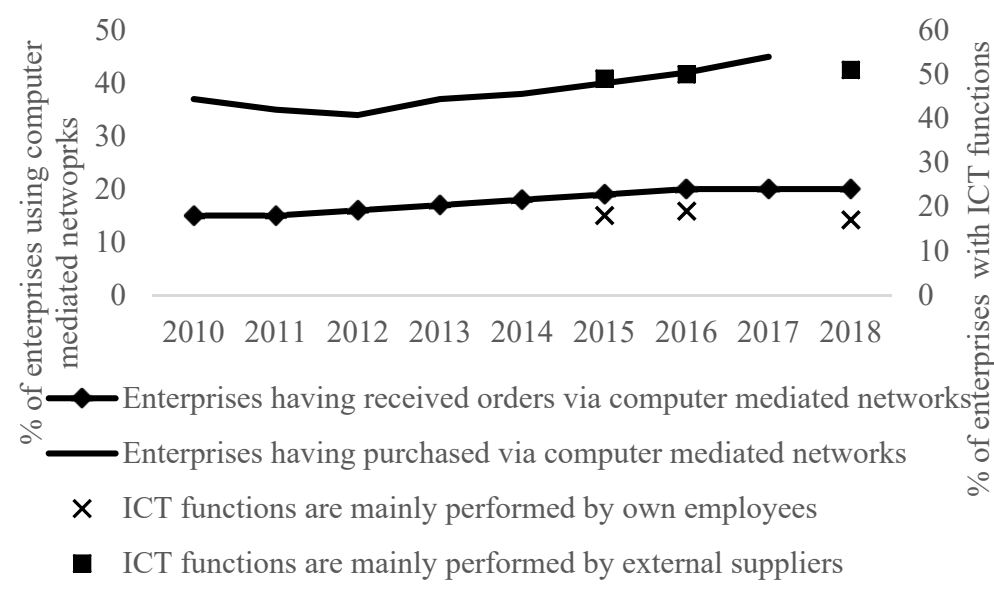

Figure 1. EU-28 enterprises performance as being engaged in e-commerce (source: Eurostat, 2019)

Automotive manufacturers have developed global online electronic markets aiming to increase efficiency and reduce costs in procurement. Online marketplaces are not restricted to the size of a company and can serve the needs of large as well SMEs from different sectors and across various regions and even the globe. Internet marketing can 
enlarge the market scope and global presence, it can replace employees performing, e.g., marketing functions. On the other hand, only a combination of functions off-line and online is crucial, in particular for SMEs (Albaum, Duerr, \& Josiassen. 2016). Market places as digital platforms enable companies to implement expansion strategies by provided global demand and tools, export through online market places grows three times faster than exports without using market places. Entrepreneurship, a collaboration between government and enterprises on established tools as market places and a simplified business environment are key success factors to enable unlimited regional and global opportunities (International Trade Center, 2017).

Digital platforms are an efficient instrument and component of the digital economy, it enables firms to cooperate, communicate and implement integrated solutions. Such platforms can possess a different degree of customer and machine involvement to develop business: consumer-to-machine, machine-to-machine transactions, smart contracts, supply chain tracking, and many others. A customer can send a request for manufacturing where a further solution can be applied for a transaction depending on platform technical features (Bahga \& Ma-disetti, 2016). Digital platforms represent a new platform economy, they are diverse in function and structure as social media, market places applied cloud tools (Davidavicienè, Raudeliunienè, \& Putrimas, 2019; Kenny \& Zysman, 2016). Finally, digital means disruptive, digitizing B2B firms lower their costs, explore the reach and quality of their offerings (Bughin, Catlin, Hirt, \& Willmott, 2018).

Internal capabilities are improved and competitiveness grows while global sourcing strategy is implemented by firms. In addition, productivity largely depends on firms involved in global networks as cost reduction, growing internationalization through performance improvement are definitive competitive advantages of importing firms (Andersson \& Stone, 2017).

Vendors need to communicate according to customers standards and they have become a fundamental approach, new communication tactics have to be applied as interactivity (Klepek \& Starzyczná, 2018; Davidaviciene, Pabedinskaite, \& Davidavicius, 2017). Despite new trends, there is a certain gap between different categories of managers to apply and adjust to new communication models. Business owners and managers are more likely to use traditional communication models rather than apply new ones (Klepek \& Starzyczná, 2018).

Beside technological infrastructure as an imminent factor to maintain components of the digital economy, the traditional business principles remain actual, such as partner search, communication, promotion conversion into sales, logistics, information and communication flows. Information technology affect international marketing in two ways: 1) trade was triggered in technology-related products and services, 2) new communication channels were developed, costs diminished and transferred information volume was increased. Technological advances contributed to a rapid acceleration of both in traditional products and in manufacturing processes (Albaum, Duerr, \& Josiassen, 2016).

The application of a variety of digital media marketing channels can enhance awareness of enterprise brands. This is essential to maintain for vendors as they constantly are looking for competitive advantages to supply their products or services. However, marketers (in our case vendors) have to consider customer's (in our case buyers) communication channels and prepare required technological platforms to maintain effective communication. On the other hand, psychological behavior has to be considered along with technical solutions. Conventional off-line communication and supplier search methods can vary among different generations. Consumers also can be skeptical for new online solutions, therefore additional benefits have to be considered to use a digital communication way (Ahmed, Vveinhardt, \& Streimikiene, 2017; Seitz, Pokrivčák, Tóth \& Plevný, 2017). Digitalization brings data overload phenomena where personal communication is diminishing. Thus, it is essential to extract and benefit with information from the data and in particular from digital communication (Kostelić \& Križman Pavlović, 2018).

Digital transformation is not only about such components as data exchange and digital platforms. However, digital economy combines technologies, solutions and ways of utilization to explore opportunities for innovation and continuously adjusted business models Furthermore, the digital economy enables regional businesses to grow beyond existing geographic areas into a global level and benefit from strategies developed on the long-term trends (Asian Development Bank, 2018).

Digital platforms can have a variety of definitions, from simple to complicated, it can be viewed from technical and sociotechnical view, it can unite technical elements such as codebases, technical elements, and associated organizational processes. Platforms can possess numerous types such as platforms for platforms (established infrastructure for the rest), enabled digital tools online and support other market places, platforms mediating work, retail and service providing (De Reuver, Sørensen, \& Basole, 2017; Kenny \& Zysman, 2016). Generally, a platform is multiple of participants to connect, interact, create and exchange value. Assadulah, Faik \& Kankanhall (2018) distinguish and overview two types of platforms as technical (e.g., software development and production) and non-technical (e.g., B2B and B2C transactions). A platform can play the role of the network of systems (Mattila \& Seppälä, 2016).

Digital platforms fulfill the role of an online community, they represent a mixture of interrelated components as software, hardware, operations and networks (Kenny \& Zysman, 2016). Networks provide with numerous of features as users are enabled to create communities, exchange information, debate and contribute to network platform content under effective and adequate advertising campaigns (Raudeliūnienè, Davidavičienè, Tvaronavičienè, \& Jonuška, 2018). 
New digital media forms as an imminent core of the fourth industrial revolution create an individual and collective perception of societies and communities, employers more and more use human cloud concept-personnel employed on remote (Schwab, 2016). Such communities inspire a sense of belonging and can be associated with a relationship. Such communities are tightly connected through essential components as commerce, communication, and content. Considerable value and relations are created through belonging to a community and interaction between customers and vendors. Communities can be four types as personal, extended, transaction-oriented and of interest. However, all these types can be oriented for commercial and non-commercial purposes (Rowley, 2002). This paper addresses the importance of communities with commercial purposes as business facilitators and does not look into purely e-commerce and business transactions related. It is a virtual trade show, facilitator and business opportunities enabler approach.

Digital platforms possess a variety of functionality: search, coordination, payment, and product delivery. Platform owners (see Figure 2) can play in one or more of the parts in a platform value chain by functions carried out. Some platform providers can play all functions (e.g., e-commerce) where other providers with a tool to search for manufacturers, sellers or service providers. However, payments have not collected either good delivered. Such platforms act as facilitators. Platform companies have a significant advantage as they enable to scale-up provided services where their operations remain highly centralized (McKinsey Global Institute, 2019). Changes in technological convergences along with industries merge which previously were separated can also force to reposition roles and relations between different actors operating in a value chain (Pon, Seppälä, \& Kenney, 2015). Offered e-services and solutions contribute to value for the customer, as well as enhances the value for the company (Dębkowska, 2017).

A general definition of a platform can be that social and economic interactions between different parties are mediated online (Kenny \& Zysman, 2016). Business market places (requests for quotations or manufacturing at B2B level) and media platforms (music, news, surveys) can be seen as forms of digital platform solutions for particular needs to serve.

Finally, digital platforms can enable users to generate revenues, reduce costs, speed up products and services to target markets and enhance collaboration.

\section{Research methodology}

A variety of stakeholders are involved in digital processes development. Technology is done by people to people. Users define nature to use devices and systems. Manufacturers aim to develop their products at low costs, it is vital for them to decide to develop locally or outsource, they are interested in producing, selling and making a profit. Networked companies and consumers are vitally important for overall competitiveness and economic growth (Institute of Electrical and Electronic Engineers, 2018; Silver, 2012).

Foreign trade experts perceive SMEs websites as a communication channel rather than a transaction platform. Information quality is the most important factor to assess SMEs website which leads to establishing reliable connections globally. Navigability reliability and accessibility are critical factors to define success for an SME on an international level (Akman \& Dagdeviren, 2016).

Andersson \& Stone (2017) presented research which shows a considerable dispersion of enterprises and their sourcing strategies. Only a few firms source a large number of products in foreign countries and the same applies to a number of sourcing countries. It provides with evidence that companies source neither a large volume of products nor search it in many foreign countries. However global sourcing through import networks and diversification contributes to higher firm competitiveness through obtained knowledge and information. In addition, EU countries possess a large unused potential of B2C e-commerce, such a feature is applied for both countries with weaker economies and also in highly developed countries (Kunešová \& Eger, 2017).

Firms have several options to promote their products and services overseas. Many public organizations as trade promotions institutions offer digital platforms in a form of industrial or export-oriented on-catalogs with integrated solutions as search engines. Firms presence is exclusively free of charge on such platforms. However, a number of alternatives are existing on the market to foster and promote international business. Therefore, we looked at different platforms from the business model perspective. Our goal was to assess purely commercially presented digital platforms. They have a very similar business model: free accessible information layer and comprehensive and valuable information and benefits through subscription and fee for a certain period of time. This model is even more widened through different sectors, not only related to research goals. As indicated, the platform owner revenue model is developed on a subscription fee to over a period of time to access information which is hidden from ordinary and public free access.

Platform owners reconsider their positions in value chain and strategies to play as a platform by creating a marketplace of goods, services or free content source of value creation is user network (McKinsey Global Institute, 2019).

Digital marketplace enables to exchange information and commercial transactions between consumers, business and government. Such solutions can include different forms, inter alia, search engines, social networks, site comparison (Chaffey, 2011). Social networks largely depend on ICT development and applied solutions, they also can be widely used in different areas of business, e.g., social supermarkets (Knezevic, Davidavičienė \& Skrobot, 2018). However, 

global opportunities

our research strictly distinguishes between digital platform applications for commercial and information purposes with a primary focus on impact by generated business opportunities through direct application on industry and services.

Demand for applied digital solutions is a key element to foster relationships between internal and external e-commerce drivers such as export market infrastructure and demand for e-commerce use. This demand drives to create relationships between environmental factors and elements of export marketing strategy (Gregory, Karavdic \& Zou, 2007). Hence, the next step was to look deeper into the essence of several platforms and analyze their operation nature through defined criteria.

Platform owner fulfills a role of information broker to enable a dialogue between customer and vendor (see Figure 2). Owners gain a market advantage as becoming more important players in the new platform economy and gaining market positions even as factory owners in earlier industrial revolutions (Kenny \& Zysman, 2016). An owner performs a number of tasks for value creation of platform users such as marketing, assurance of continuous flow of information, solutions for content uploads, options to select or receive demanded information. Vendors are understood as service providers, manufacturers or suppliers, looking for new market opportunities. They are usually charged for a certain fee to submit information and perform outreach activities to build a network, strengthen a brand, enhance and maintain awareness of delivered products and services through commercialized activities. Platform owners consider different approach strategies to promote and make their platform eligible for vendors to use. Some of such platforms act and are open for vendors globally, some act just as regional players in a closed network by providing services on a restricted approach from defined countries.



Figure 2. Digital platform architecture and interaction between platform users and platform owners (source: own elaboration)

The research was structured on the two-fold model: 1) to analyze eight models of digital platforms as solutions for on-demand manufacturing capacity or consulting service provider on an accumulated expertise view by interviewed vendors which use different solutions provided by digital and media platforms (see Table 1); 2) to interview vendors and benchmark their approach and expectations against digital platform owners approach (see Figure 3).

Data about these platforms was extracted from online sources according to assessment criteria. Digital and media platforms represented several broader and key sectors like engineering, packaging and consulting. These sectors were selected on a basis by available access and later the possibility to interview vendors. We used an approach to different platforms and grouped into digital, network, media or marketplace according to a definition of platform owners. Some regionally operating platforms within a certain geographic region operate and are integrated with technical functionalities on large global platforms (e.g., Google) by providing certain competitive advantages for customers using smaller platforms but gaining global access. Analyzed digital platforms provided with an option to use certain software solutions (integrated with the platform) as a ranking of incoming requests as B2B platform, segmentation, and search by deeper categories of manufacturing operations and other benefits.

As we analyzed, platform owners use different definitions on their solutions. Generally digital platform models were defined by the following criteria: 1) digital portal with a full fledge integrated technical solutions, buyers and vendors network, pricing, sales order functionalities, digital handling of purchase, integration with vendors ERP (enterprise resource planning system); 2) market place in a form of a network connecting customers and vendors and received quotations via market place, it aggregate data, but it is not integrated in the chain of data between two players, the decision and task is left for them; 3) a network of firms was defined as an online community where business is 

global opportunities

facilitated online, later uploaded and received information is communicated outside the platform functionality area; and finally 4) media platform were defined as a purely online information exchange (McKinsey Global Institute, 2019; Assadulah, Faik, \& Kankanhall, 2018; De Reuver, Sørensen, \& Basole, 2017; McKinsey Global Institute, 2016; Kenny \& Zysman, 2016).

We distinguished in definition as users under customers and vendors as a product manufacturer or supplier or service provider, two major stakeholder groups (see Figure 1). However, vendors were an exclusive target group to be analyzed by the created value of digital platforms under the benchmarking approach of these platforms and assessing expected benefits generated through these platforms for vendors (see Table 1).

As platform primary goal is to facilitate business between two parties as customers (usually buyers) and vendors (suppliers), the number of existing members can show the level of popularity of a platform, it also gives an indication on impact scale (global or regional). On the other hand, business facilitated through digital platforms can have certain limitations as an impact of transport costs to deliver or cultural differences embarking in communication between two parties when business is being established (Albaum, Duerr, \& Josiassen. 2016). A digital solution can't replace entirely these two important factors and they need to be considered while assessing the impact and advantages of platforms. Finally, in particular, for SMEs with expansion strategy, significant costs will arise to build and maintain awareness globally where they simply can risk spending their resources by using a platform with global coverage. Firms usually start entering and maintaining business from neighboring markets (Brazinskas, 2015).

The number of registered vendors and received requests for products and services indicated a coverage and awareness of a defined platform to be known and used regionally or globally.

The research goal was not to go deeply in technical functionalities of solutions, but rather to assess opportunities and advantages provided by these platforms for vendors. Furthermore, only on-line use and promotion of a platform are less likely to be effective for users. Therefore, a combination of online solutions as a digital platform along with off-line in-house support (promotion, coaching, and vendor lead through the access time period, additional benefits as marketing support, training) can give a broader specter of benefits for a user and expand their created value.

Table 1. Benchmarking of selected and assessed digital platforms (source: own compilation)

\begin{tabular}{|l|c|c|c|c|c|c|c|c|}
\hline \multirow{2}{*}{ Criteria } & \multicolumn{9}{|c|}{ Digital platform } & $\mathrm{g}$ & $\mathrm{h}$ \\
\cline { 2 - 9 } & $\mathrm{a}$ & $\mathrm{b}$ & $\mathrm{c}$ & $\mathrm{d}$ & $\mathrm{e}$ & $\mathrm{f}$ & $\mathrm{g}$ \\
\hline Sectoral dimension & $\begin{array}{c}\text { Engi- } \\
\text { neering }\end{array}$ & $\begin{array}{c}\text { Engi- } \\
\text { neering }\end{array}$ & $\begin{array}{c}\text { Packag- } \\
\text { ing }\end{array}$ & $\begin{array}{c}\text { Engi- } \\
\text { neering }\end{array}$ & $\begin{array}{c}\text { Engi- } \\
\text { neering }\end{array}$ & $\begin{array}{c}\text { Engi- } \\
\text { neering }\end{array}$ & $\begin{array}{c}\text { Con- } \\
\text { sulting }\end{array}$ & $\begin{array}{c}\text { Con- } \\
\text { sulting }\end{array}$ \\
\hline Assigned platform type & $\begin{array}{c}\text { Net- } \\
\text { work }\end{array}$ & $\begin{array}{c}\text { Market- } \\
\text { place }\end{array}$ & $\begin{array}{c}\text { Market- } \\
\text { place }\end{array}$ & Portal & Network & $\begin{array}{c}\text { Net- } \\
\text { work }\end{array}$ & Media & Media \\
\hline Geographic coverage & Europe & Europe & Global & $\begin{array}{c}\text { Re- } \\
\text { gional }\end{array}$ & Global & $\begin{array}{c}\text { Re- } \\
\text { gional }\end{array}$ & Global & Global \\
\hline Off-line marketing support & No & Yes & No & Yes & No & Yes & No & No \\
\hline $\begin{array}{l}\text { Number of registered vendors } \\
\text { (manufacturers, suppliers, service } \\
\text { providers), } n\end{array}$ & 900 & 21000 & 4000 & $\mathrm{n} / \mathrm{a}$ & $\mathrm{n} / \mathrm{a}$ & 12000 & 970000 & 64000 \\
\hline $\begin{array}{l}\text { Number of requests per year for } \\
\text { registered vendor products or ser- } \\
\text { vices, } p\end{array}$ & $\mathrm{n} / \mathrm{a}$ & 25000 & 1200 & $\mathrm{n} / \mathrm{a}$ & $\mathrm{n} / \mathrm{a}$ & 1500 & 90000 & 80000 \\
\hline Request impact ratio, $r$ & $\mathrm{n} / \mathrm{a}$ & 1.19 & 0.3 & $\mathrm{n} / \mathrm{a}$ & $\mathrm{n} / \mathrm{a}$ & 0.13 & 0.09 & 1.25 \\
\hline
\end{tabular}

Finally, we calculated request impact ration $(r)$ as a probability to a vendor to develop business, one of the major direct merits of a platform to contribute to commercial value creation of a vendor. Impact ratio of received requests per registered vendor

$$
r=\frac{p}{n},
$$

where: $r$ - request impact ratio; $p$ - a number of requests per year for registered vendor services, $n-$ a number of registered vendors).

The methodology provided in table 1 is used to benchmark platforms by external factors through defined and selected criteria. However, a broader picture was needed to assess vendors view on provided solutions of analyzed platforms. Vendors were interviewed from expert view and their feedbacks calculated and assessed while evaluating overall assessment by vendors and platform owners. We looked at seven criteria and received feedback on it (see Figure 3). This stage largely depended on firms aims to explore international strategies. Internal capabilities are one of the key factors to define a firms sourcing strategy. Productivity largely depends on global network growth (Andersson 

global opportunities

$\&$ Stone, 2017). A source is an ecosystem that defines value created by a platform. This ecosystem determines the rules by which users (in our case vendors) can participate (Kenny \& Zysman, 2016).

Selected seven interview criteria represented key feedbacks from the vendors' side. As usual, they get access to such platforms under the defined fee, the requirements were placed at a number of received requests for a particular product. In addition, in particular, market places and network-based platforms compete with conventional forms of business facilitating such as trade fairs, off-line B2B matching sessions or similar. These latter tools are better known historically, have been proven or firms attendance is stimulated and often co-financed by government support. As an example, the European Commission through Horizon 2020 implements a program "Manufacturing Industry Digital Innovation Hubs" where digital platforms providers will be able to get access and connected to the real world (European Commission, 2017).

Some platforms deliver online service through purely digital solutions, other available digital solutions combine with off-line support to customers, e.g., sales or marketing assistance provided by platform owner personnel. Platform examples in the digital economy can be similar to Xometry, Factory (industry), Assorted, AIC2000, DreamApply (services) and others.

In addition to standard questions, all managers were asked to provide with any comments which would complement and enhance the importance of their feedback. This is an essential part that demonstrates a variety of internal situations and differences at the same international trade-related factor facilitated through a platform. Comments also gave feedback on views differences between owners and hired managers as they were treated as one single group as top managers. Various digital platforms for e.g., media, services connect buyers and sellers directly, coordination is speeded up and costs lowered between buyers and sellers (McKinsey Global Institute, 2019).

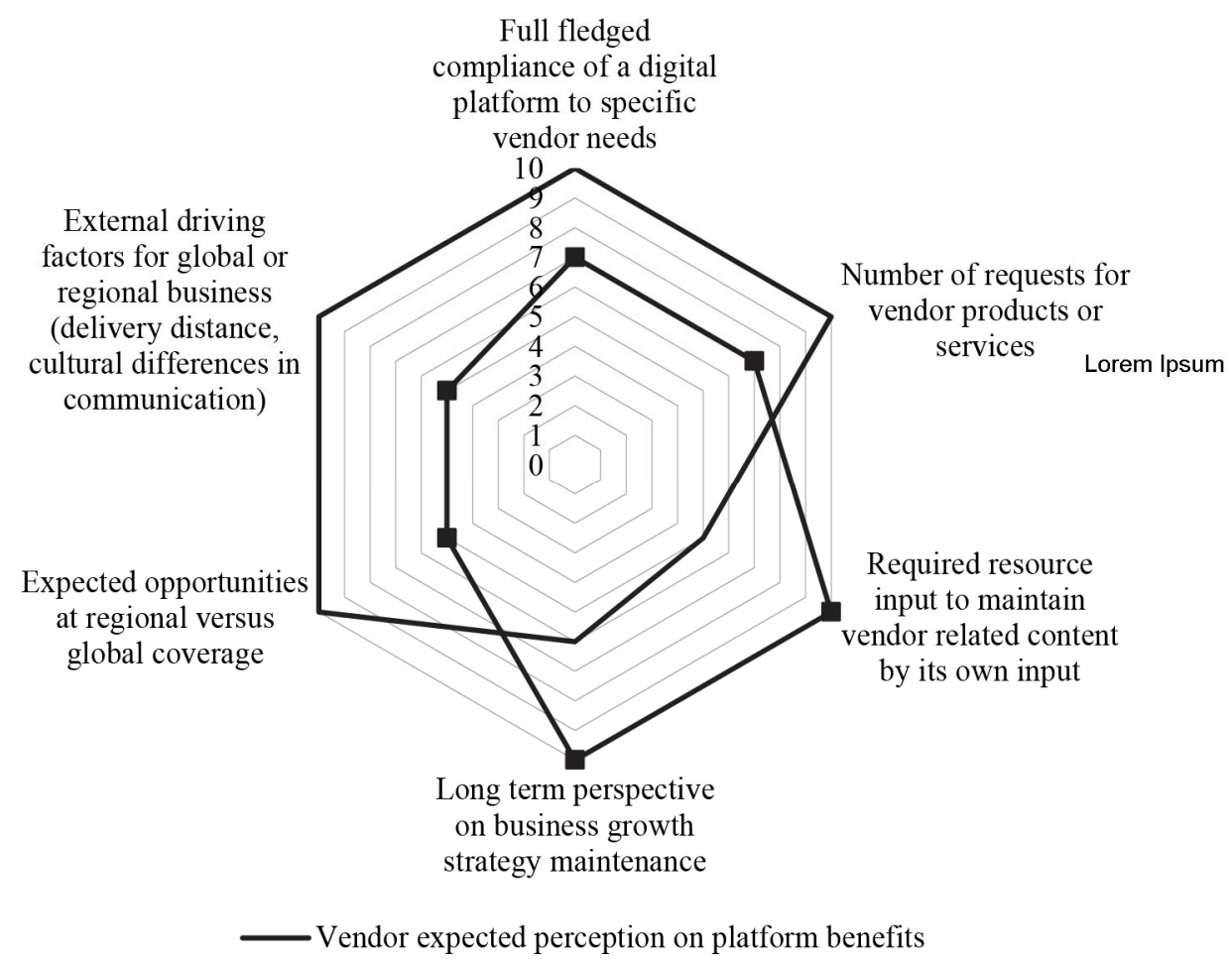

Figure 3. Deviation by behavior on digital platform service perception by assessment criteria, accumulated results (source: own elaboration)

Digital platforms can enable users to generate revenues, reduce costs, speed up products and services to target markets and enhance collaboration. They reshape existing business models by resetting entry barriers, changing the logic of value creation (Kenny \& Zysman, 2016).

\section{Results}

Digital platforms provide with market place solution that connects buyers and sellers, they enable users to generate revenues, reduce costs, speed up products and services to target markets and enhance collaboration (McKinsey Global Institute, 2016). The online assessment has proven that there is a variety of platforms operating on markets and even differences between their types are not very significant, we presume that platform operators use different definitions to assign their solutions to specific platform models (see Table 1). 
Geographic coverage of business facilitation is criteria according to its platforms can be grouped in global or regional business enablers. Off-line support is a significant advantage as considerable business is still done via traditional channels by involved intermediaries. Platforms with such function can gain better market advantages.

Impact ratio is a considerable decision making factor for a vendor to select a suitable platform and it can be a competitive advantage of a platform. Vendors expectations are large to get as more as possible requests along with a high degree to meet their product or service range by incoming requests. However, this ratio does not judge specifically and provide with unique and exceptional advice to select a platform.

Vendors interviews hexagon provides with results of disparities on certain factors approach in comparison to platform owners views. A significant mismatch is obvious between these two approaches (see Figure 3). Vendors expect a high number of incoming requests and level of guarantees to benefit from compliance of these incoming requests to their products or services to be delivered. They are realistic to assess regional or global market opportunities enabled through a platform and see regional aspect and opportunity as a priority, including the importance of factors as geographic proximity.

However, different approaches and opposite expectations were identified while assessing on two other factors: 1) platform owners provide with an instrument of a long or medium-term perspective strategy development to facilitate established network between vendors and customers where vendors expect much quicker results to obtain benefits generated through a platform on a short-term period. Furthermore, platforms require constant maintenance, content updates, information actuality supervision, it is less likely to be left without monitoring as vendors competitiveness can be diminished by jeopardized obsolete information about vendors benefits, products, and services. Vendors treat this factor (content update) with a lower degree of importance. However, platform owners provide with a number of additional functionalities as digital newsletters by taking information from vendors business profiles placed on a platform. As such newsletters usually have thousands of subscribers, such advantage can strengthen awareness about vendors offering and extend a network of potential customers.

Research of platform features and vendors approach benchmarking against platform owners vision disclosed the growing role of platforms as business enablers with regional and global opportunities depending on delivered products and services. In addition, the research has demonstrated existing disparities in approach between vendors and platform owners.

\section{Conclusions}

The paper examines how digital platforms shape the pattern of firm strategies, collaboration and what opportunities they bring. As the role and importance of computer-mediated networks grows, firms need to pay constant attention to arising challenges and opportunities to maintain their competitiveness. Platforms as an external force motivate and enable companies to enlarge the degree of integration between suppliers, manufacturers, service providers, and buyers, identify right positioning in a value chain, expand networks, create clusters to collaborate, define market entry strategy and work in a community-related environment.

Platforms provide with limitless advantages and embark various sectors of business beyond existed areas and foster users competitiveness. Even knowledge related portals emerge under embedded technologies, stakeholders as workers and cooperation partners can share common goals under wide application as an exchange of information, data, texts, such portals play a role of knowledge related tasks (Mack, Ravin, \& Byrd, 2001).

Therefore, we argue that vendors expectations can mislead platform model selection, if this process has a limited number of assessment factors as, e.g., single impact ratio only. Firms need to apply a broader approach and assess regional and global coverage, numbers of registered vendors and unique users and other factors. Competition degree requires a need to assess by a vendor its ability to run business regionally or globally: from one hand expect to receive a larger number of inquiries, but at the same time to compete with bigger number of suppliers from other parts of the world or to focus on regional approach instead where cultural differences do not differ much from vendor physical manufacturing or service providing location, shipment costs and lead time burden contain a lower share in costing and pricing. Furthermore, firms need to apply a wider approach and go beyond the existing traditional assessment system, e.g., consider an important assessment factor as data traffic analysis (number of unique users over a period of time, page view or visitors) provided by a third party information provider.

Our main argument is manifold: 1) digital platforms are getting more important and powerful phenomena to foster vendor-buyer integration through established networks and communities; 2) despite the united approach on arising opportunities, there are significant disparities on provided digital platforms benefits; 3) while selecting a platform, several criteria have to be considered and not limit with a single one; 4) regional or global impact of a platform is a considerable selection factor; 5) that despite a global approach through networks and sourcing channels, a regional dimension remains an important factor to focus on business implementation strategy.

Platforms facilitate communities that unite players driven by sector specialization, value creation and positioning it such chains, clusters establishment. Cluster features play a crucial role in such a network driven community between vendors, buyers, and platform owners. Sölvel (2009) defines six major components in clusters as an industry, finances, 
media, public bodies, universities and organizations for collaboration (formal and informal networks, trade associations, cluster organizations). Platform owners operate their business beyond their traditional online solutions as they publish sectoral digital and printed magazines, provide with newsletters feeds with vendors information through their profiles on digital platforms, carry on surveys on industry trends and other advantages for being a member of a cluster run community.

The study has several limitations, which were beyond this paper's scope to address. First, a sectoral definition of digital platforms that were analyzed. This study has covered B2B linked platforms as industrial engineering, packaging and consulting services related. Second, platforms have open and hidden levels of an accessible level, the latter level is confidential such as a number of vendors with advanced services or generated order value. Thus, comprehensive data mining can be limited. Third, every sector as industrial engineering, packaging or consulting possesses many specific subsectors (automotive, metal processing, consumer products or exclusive packaging, diverse consulting) with different demand and as a consequence different benefits can be provided by a platform to vendors. Forth, platform owners and vendors look from different perspectives (supply-demand) to provide with platform solutions or to use it, the expectations gap can be volatile and more difficult to be measured. Fifth, digital solutions diminish the border between regions and open global opportunities. However, it can't be equally applied for products and services at the same degree. Thus, result fragmentation might appear and research results application across sectors and models of platforms can be used with certain reservations.

The research possesses novel aspects as it focuses on the relationship between vendors and digital platform owners through observed several types of digital platforms. Strong evidence shows the growing demand for new integrated communication tools between vendors and buyers through facilitated computer-mediated networks. Depending on product or service delivered, platforms enable to research a high degree of scaling, despite regionally or globally. Longterm strategy application, vendors own commitment to monitor and update their own profiles placed on platforms belong to factors where vendors need to pay constant attention and maintain proper information. In conclusion, there is no one single approach to define an impact by one single factor. Only a win-win strategy approach between a platform owner and vendors can lead to mutual benefits in business model acceptance and growth utilizing arising global and regional opportunities.

\section{Disclosure statement}

We declare that we do not have any competing financial, professional, or personal interests from other parties.

\section{References}

Ahmed, R. R., Vveinhardt, J., \& Streimikiene, D. (2017). Interactive digital media and the impact of customer attitude and technology on brand awareness: evidence from the South Asian countries. Journal of Business Economics and Management, 18(6), 1115-1134. https://doi.org/10.3846/16111699.2017.1400460

Akman, E., \& Dagdeviren, M. (2016). Discovering what makes an SME website good for international trade. Technological and Economic Development of Economy, 27(3), 1063-1079. https://doi.org.10.3846/20294913.2016.1266709

Albaum, G., Duerr, E., \& Josiassen, A. (2016). International marketing and export management. Essex: Pearson Education, (pp. 35-335).

Andersson, M., \& Stone, T.-A. (2017). Global sourcing and technical efficiency - a firm-level study on the ICT industry in Sweden. Journal of Business Economics and Management, 18(5), 877-896. https://doi.org/10.3846/16111699.2017.1356367

Assadulah, A., Faik, I., \& Kankanhall, A. (2018). Digital platforms: A review and future directions. Twenty Second Pacific Asia Conference on Information Systems, Japan 2018.

Asian Development Bank. (2018, February). Understanding the digital economy: What is it and how can it transform Asia? Retrieved from www.adb.org/news/events/understanding-digital-economy-what-it-and-how-can-it-transform-asia

Bahga, A., \& Ma-disetti, V. K. (2016). Blockchain platform for industrial internet of things. Journal of Soft-ware Engineering and Applications, 9, 533-546. https://doi.org/10.4236/jsea.2016.910036

Brazinskas, S. (2015). Foreign market selection methods in a changing international trade environment. In The International Conference „Contemporary Issues in Business Management and Education 2015 “. Vilnius, Lithuania, 12 November, 2015.

Brazinskas, S. (2018). Digital industrial platforms as enablers of a closer Nordic integration. Baltic Rim Economies, October 2018, 49(3). Retrieved from www.utu.fi/sites/default/files/media/drupal/BRE_3_2018.pdf

Bughin, J., Catlin, T., Hirt, M., \& Willmott, P. (2018). Why digital strategies fail. McKinsey Quarterly, January 2018. Retrieved from www.mckinsey.com/business-functions/digital-mckinsey/our-insights/why-digital-strategies-fail

Chaffey, D. (2011). E-business \& E-commerce management. Essex: Pearson Education Limited, (pp. 49-66).

Cisneros-Cabrera S., Ramzan A., Sampaio P., \& Mehandjiev, N. (2017). Digital marketplaces for industry 4.0: A survey and gap analysis. IFIP Advances in Information and Communication Technology. 506. Cham: Springer. https://doi.org/10.1007/9783-319-65151-4_2

Davidavicienė, V., Raudeliunienè J., \& Putrimas, S. (2019). Communication needs in cyberspace of industrial companies' consumers. International Journal of ICT Research in Africa and the Middle East (IJICTRAME), 8(1), 41-58. https://doi.org/10.4018/IJICTRAME.2019010104 
Davidaviciene, V., Pabedinskaite, A., \& Davidavicius, S. (2017). Social networks in B2B and B2C communication. Transformations in Business \& Economics, 16(1), 69-84.

Dębkowska, K. (2017). E-services in business models of enterprises in the logistics sector. Business: Theory and Practice, 18(1), 79-87. https://doi.org/10.3846/btp.2017.009

De Reuver, M., Sørensen, C., \& Basole, R. H. (2017). Marketing communication model for social networks. Journal of Information Technology, 33(2), 124-135. https://doi.org/10.1057/s41265-016-0033-3

ETLA, Research Institute for the Finnish Economy. (2018). Work and wealth in the era of digital platforms. Retrieved from Internet: www.etla.fi/en/research/work-and-wealth-in-the-era-of-digital-platforms/

European Commission. (2018). Digital economy and society index report 2018. Retrieved from https://ec.europa.eu/digital-singlemarket/en/news/digital-economy-and-society-index-2018-report.

European Commission. (2017). Manufacturing industry digital innovation hubs. Retrieved from https://cordis.europa.eu/pro$\mathrm{ject} / \mathrm{rcn} / 211689 /$ factsheet/en

Eurostat. (2019). Digital economy and society statistics - enterprises. Retrieved from https://ec.europa.eu/eurostat/statistics-explained/index.php/Digital_economy_and_society_statistics_-_enterprises\#E-business_integration

Gregory, G., Karavdic, M., \& Zou, S. (2007). The effect of e-commerce drivers on export marketing strategy. Journal of International Marketing, 15(2), 30-57. https://doi.org/10.1509/jimk.15.2.30

Institute of Electrical and Electronic Engineers. (2018). Internet of Things A to Z (pp. 8-67). New Jersey: Wiley,

International Trade Center. (2016). Creating an inclusive digital economy is vital to achieving the SDGs. International Trade Forum. The digital economy, 2, 16-19. Retrieved from www.intracen.org/uploadedFiles/Common/Content/TradeForum/Trade_Forum_2_2016_20160701_ITC\%20Digital\%20Printing_web_pages.pdf

International Trade Center. (2017). On-line market places as business enablers. In World Export Development Forum 2017, Budapest, Hungary.

Izgorodin, A. (2018). Lithuanian manufacturing: Rapid growth accompanied by challenges. Baltic Rim Economies, October 2018, 50(3). Retrieved from www.utu.fi/sites/default/files/media/drupal/BRE_3_2018.pdf.

Kenny, M., \& Zysman, J. (2016). The rise of the platform economy. Issues in Science and Technology, September 2016, (pp.6169). Retrieved from www.nbp.pl/badania/seminaria/25x2016_2.pdf.

Kitchin, R. (2014). The data revolution. London: Sage Publications, (pp. 158-160).

Klepek, M., \& Starzyczná, H. (2018). Marketing communication model for social networks. Journal of Business Economics and Management, 19(3), 500-520. https://doi.org/10.3846/jbem.2018.6582

Knezevic, B., Davidavičienè, V., \& Skrobot, P. (2018). Implementation of social networks as a digital communication tool in social supermarkets. International journal of modern research in engineering \& management (IJMREM), 1(6), 41-52.

Kostelić, K., \& Križman Pavlović, D. (2018). Econometric assessment of customers' personality biases and communication preferences correlation. E+M Ekonomie a Management, 21(3), 141-154. https://doi.org/10.15240/tul/001/2018-3-009

Kunešová, H. \& Eger, L. (2017). Evaluation and comparison of B2C e-commerce intensity in EU member states. E+M Ekonomie a Management, 20(4), 151-167. https://doi.org/10.15240/tul/001/2017-4-011

Mack, R., Ravin, Y., \& Byrd, R. J. (2001). Knowledge portals and the emerging digital knowledge workplace. IBM Systems Journal, 40(4), 925-955. https://doi.org/10.1147/sj.404.0925

Mattila, J., \& Seppälä, T. (2016). Digital Trust, Platforms, and Policy. ETLA, 42. Retrieved from http://pub.etla.fi/ETLA-MuistioBrief-42.pdf

McKinsey Global Institute. (2019). Globalization in transition: The future of trade and value chains. McKinsey \& Company, (pp. 50-110).

McKinsey Global Institute. (2016). The age of analytics: competing in a data-driven world. McKinsey \& Company, (pp.19-50).

OECD. (2017). OECD Digital Economy Outlook 2017. OECD Publishing. https://doi.org/10.1787/9789264276284-en

Pon, B., Seppälä, T., \& Kenney, M. (2015). One ring to unite them all: Convergence, the smartphone, and the cloud. Journal of Industry, Competition and Trade, 15(1), 21-33. https://doi.org/10.1007/s10842-014-0189-x

Raudeliūnienė, J., Davidavičienė, V., Tvaronavičienė, M., \& Jonuška, L. (2018). Evaluation of advertising campaigns on social media networks. Sustainability, 10(4), 1-14. https://doi.org/10.3390/su10040973

Rowley, J. (2002). E-business: principles and practice. London: Palgrave, (pp.148-165).

Seitz, C., Pokrivčák, J., Tóth, M., \& Plevný, M. (2017). Online grocery retailing in Germany: an explorative analysis. Journal of Business Economics and Management, 18(6), 1243-1263. https://doi.org/10.3846/16111699.2017.1410218

Schwab, K. (2016). The fourth industrial revolution. World Economic Forum (pp. 30-112).

Silver, S. D. (2012). Networked consumers. Dynamics of interactive consumers in structured environments. London: Palgrave MacMillan, 138-146. https://doi.org/10.1057/9780230362550

Sölvel, Ö. (2009). Clusters. Balancing Evolutionary and Constructive Forces. Stockholm: Ivory Tower.

Stephens-Davidowitz, S. (2017). Everybody lies. What the internet can tell us about who we really are. London: Bloomsbury. 